\title{
Postscript:
}

\section{The Trouble with Schiller}

I treat bones as a text, on which all life and all that is human can be said to depend.

-Goethe to Lavater, 14 November 1781

When I find a scattered skeleton, I can gather it [zusammenlesen] and put it together; for here eternal reason speaks through an analogue, even if the skeleton be a giant sloth.

-Goethe, "Reflections in the Spirit of the Wanderers," Wilhelm Meisters Wanderjahre (307/311)

We have had occasion to note that it is a matter of some dispute where Wilhelm Meisters Wanderjahre ends. After Wilhelm's resurrection of Felix, which Eric Blackall understandably calls the "real ending of the novel" (Goethe and the Novel, 259), there follow, if one's edition follows the Ausgabe letzter Hand-the edition of Goethe's works that received the author's final corrections-a collection of maxims and a poem. The rationale for their inclusion is a matter of anecdote and inference. According to Eckermann, Goethe added the maxims because the second and third books of the Wanderjahre were too short: he gave Eckermann "two large bundles of manuscript" and instructed him to use them to "fill the gaps of the 'Wanderjahre,'" adding that "strictly speaking this material has nothing to do with [the novel], but it can be justified by the fact that mention is made of an archive at Makarie's place, in which such pieces [Einzelheiten] are to be found." 1 At the same time, according to this account, Goethe decided to use this opportunity to publish two poems he had written a few years earlier. Eckermann, therefore, divided the maxims into two groups, entitled one "Reflections in the Spirit of the Wanderers" and the other "Out of Makarie's Archive," and appended them to the second and third books of the text respectively, with a poem attached to the end of each collection of aphor-

1. Johann Peter Eckermann, Gespräche mit Goethe in den letzten Jahren seines Lebens (Munich: C. H. Beck, 1984), 431-32 (15 May 1831). 
isms. ${ }^{2}$ The poem appended to the third book, and thus to the very end of the sequence of texts that the Ausgabe letzter Hand assembles as Wilhelm Meisters Wanderjahre, was never given an official title. Goethe referred to it in his journal only as "Terzinen" ("Terza rimas"), and once in a letter as "Schillers Reliquen."

Schiller had been buried in the cemetery of the Jakobskirche in Weimar, in the so-called Kassengewölbe: a common grave for citizens of distinction who did not own their own burial plots. In 1826, two decades after the poet's death, the cemetery was slated for destruction, and the Burgermeister, Carl Lebrecht Schwabe, undertook to rescue Schiller's remains. Schwabe collected twenty-three skulls, and was struck by the "noble, regular form" of one in particular; ${ }^{3}$ he compared it to Schiller's death mask, consulted three Weimar doctors, and sought corroboration from everyone in the area who had known Schiller: opinion was unanimous that he had found the right skull. The jawbone was missing; it too was identified; and two anatomical experts from Jena subsequently pieced together the bones of Schiller's skeleton, listing the recovered and the missing bones in an official burial report. The skull spent a little while enshrined in the base of a bust of the poet in the ducal library at Weimar and was then kept by Goethe at his home; a year later, it and the other remains were "arranged in the shape of a skeleton" in a sarcophagus, and laid to rest in the Royal Crypt. ${ }^{4}$

2. Eckermann goes on to report that Goethe instructed him to put the supplemental material "where it belonged" in subsequent editions of his work, so that "without the maxims and the two poems, the Wanderjahre could be reduced to two books, as was originally the intention" (Gespräche mit Goethe, 432). Eckermann's account has been called into question; furthermore, early plans for the Wanderjahre include mention of some sort of collection of maxims: see Max Wundt, Goethes Wilhelm Meister (Berlin: Goschen, 1913), 493ff. Thus some scholarly editions of the Wanderjahre, such as the Hamburger Ausgabe, include the maxims but omit the poems. 3. Cited in Karl Viëtor, "Goethes Gedicht auf Schillers Schädel," PMLA 59 (1944): 142. The details of Schiller's exhumation and reburial being recounted here are taken from Viëtor's erudite study.

4. Whether this reconstruction was actually composed of Schiller's bones was a matter of so much subsequent dispute that in the early twentieth century a second skeleton, chosen through more scientific procedures, was installed in the crypt. For a full account, see Viëtor, "Goethes Gedicht" 146 n. 6, and Max Hecker, Schillers Tod und Bestattung (Leipzig: Insel Verlag, 1935). Hecker's book is also responding to an anti-Semitic pamphlet circulated in 1928 by Mathilde von Ludendorff-wife of the general, and the animating spirit of a far-right circle. The pamphlet, "Der ungesühnte Frevel" ("The unatoned crime"), ascribed Schiller's death-and Luther's, Lessing's, and Mozart's-to the machinations of "a combination of Jews, Jesuits, and Freemasons," and explained that Schiller had been secretly buried in a "mass grave" in order to avoid an autopsy. The pamphlet drew numerous responses apart from Hecker's: that of the physician Wolfgang Veil, "Schillers Krankheit" (1936), is now available in reprint, with an extract from von Ludendorff's pamphlet, in Rudolf A. Kühn, ed., Schillers Tod (Jena: Universitätsverlag Jena, 1992). In the wake of this pamphlet exchange, Goebbels banned all further discussion of Schiller's death and had the offending texts confiscated-including Mathilde von 
Goethe's attitude toward these archeological-funerary endeavors displays an ambivalence similar to that dramatized in the stories of burial and disinterral which punctuate the Wilhelm Meister novels. He delegated his son to take his place at the ceremonials, and in various ways let it be known that he would have preferred to have had Schiller's remains reinterred without public display-as though the sleep of the dead were one of those secrets "best not disturbed," as the jeweler in the Wanderjahre says of the mysterious Kästchen (458/416). But skulls and skeletons form part of the plot of Goethe's destiny: this famous osteologue, the discoverer of the human intermaxillary bone, who had "treat[ed] bones as a text, on which all life and all that is human can be said to depend, ${ }^{\prime 5}$ was not able to remain entirely aloof from the project of recuperating Schiller: though he distanced himself from the public consecration of the remains, he attached enough importance to the skull to keep it in his study for a few months; and though he kept it in great privacy, ${ }^{6}$ at some point during this period he wrote a poem that, as noted above, for no clear reason he included for publication with Wilhelm Meisters Wanderjahre. The poem, one of Goethe's rare experiments in terza rima, reenacts the gestures of quest, violation, and consecration that its author had shunned, as a first-person narrator repeats Burgermeister Schwabe's epiphany:

Im ernsten Beinhaus wars, wo ich beschaute, Wie Schädel Schädeln angeordnet paßten;

Die alte Zeit gedacht ich, die ergraute.

Sie stehn in Reih geklemmt, die sonst sich haßten, Und derbe Knochen, die sich tödlich schlugen, Sie liegen kreuzweis, zahm allhier zu rasten.

Entrenkte Schulterblätter! was sie trugen, Fragt niemand mehr, und zierlich tätge Glieder, Die Hand, der Fuß, zerstreut aus Lebensfugen.

Ludendorff's, which had always been something of an embarrassment because it had fingered Goethe, another national hero, as an acccessory to Schiller's murder. Georg Ruppelt has a useful account of the Ludendorff affair in his fascinating study, Schiller im nationalsozialistischen Deutschland (Stuttgart: J. B. Metzlersche Verlag, 1979), 20-23.

5. WA, 4:5, 217 (to Lavater, 14 November 1781); cited in Viëtor, "Goethes Gedicht," 157.

6. Wilhelm von Humboldt claimed to have been the only visitor allowed to see it, and also noted that Goethe asked him not to narrate the experience: "[E]r hat mich sehr gebeten, es hier nicht zu erzählen." Wilhelm to Caroline von Humboldt, 29 December 1826; cited in Viëtor, "Goethes Gedicht," 145. 
Ihr Müden also lagt vergebens nieder,

Nicht Ruh im Grabe ließ man euch, vertrieben

Seid ihr herauf zum lichten Tage wieder,

Und niemand kann die dürre Schale lieben, Welch herrlich edlen Kern sie auch bewahrte.

Doch mir Adepten war die Schrift geschrieben,

Die heiligen Sinn nicht jedem offenbarte,

Als ich inmitten solcher starren Menge

Unschätzbar herrlich ein Gebild gewahrte,

$\mathrm{Da} ß$ in des Raumes Moderkält und Enge

Ich frei und wärmefühlend mich erquickte,

Als ob ein Lebensquell dem Tod entspränge.

Wie mich geheimnisvoll die Form entzückte!

Die gottgedachte Spur, die sich erhalten!

Ein Blick, der mich an jenes Meer entrückte,

Das flutend strömt gesteigerte Gestalten.

Geheim Gefäß! Orakelsprüche spendend,

Wie bin ich wert, dich in der Hand zu halten?

Dich höchsten Schatz aus Moder fromm entwendend Und in die freie Luft, zu freiem Sinnen,

Zum Sonnenlicht andächtig hin mich wendend.

Was kann der Mensch im Leben mehr gewinnen, Als daß sich Gott-Natur ihm offenbare?

Wie sie das Feste läßt zu Geist verrinnen

Wie sie das Geisterzeugte fest bewahre. ${ }^{7}$

It was in the solemn bonehouse, where I beheld

How skull arranged matched skull:

I thought of bygone time, turned gray.

Wedged in rows they stand, who each once hated each,

And sturdy bones, which fought in deadly struggle,

Lie crosswise, all tamely resting here.

7. Quoted from Wilhelm Meisters Wanderjahre, ed. Gerhard Küntzel, AA, 8:520-21. The painfully literal translation that follows is mine. 
Unjointed shoulder blades! what they bore None now will ask, and delicate, active limbs, Hand, foot, scattered out of life's joint.

You weary ones lay vainly down, They leave you no peace in the grave: driven You'll be, up to the light of day.

And no one can love these dry shells That once a glorious, noble kernel held.

But for me, initiate, was the writing written,

The holy meaning not to all revealed, As amid such a rigid crowd I saw Inestimably glorious, a shape,

Such that in the chamber's moldy cold and cramp I felt free and warmed, refreshed, As though a life-spring sprang from death.

How this form, mysterious, delighted me! The god-thought trace, which yet survived! A glance, which took me to that sea,

Which, flooding, streams forth heightened shapes.

Mysterious vessel! Giving oracles,

How am I worthy to hold you in my hand?

Highest treasure, piously from mold purloining you

And into free air, to free sense,

To sunlight reverently making my way.

What more can man gain in life,

Than that God-Nature reveal herself to him?

How what is firm she has melt into spirit,

How what spirit creates she firmly preserves.

On the rare occasions when this poem has been read, it has been interpreted as a "natural philosophy poem," a celebration of the "mysteries of nature's organization," in Karl Viëtor's phrase ("Goethes Gedicht," 173): mysteries that, like the "idea" in the Goethean symbol, would remain "effective and unreachable in the image." But the decent obscurity of an encrypted body or meaning is precisely what the poem's narrator violates 
in order to affirm, which is doubtless one reason why the symbolic interpretation has failed to elicit much satisfaction even in the critics who advance it. ${ }^{8}$ We thus have an opportunity to advertise the utility of rhetorical reading: in the wake of our examination of the Wilhem Meister novels, the appearance of this poem was almost foreseeable. The Meister texts have figured their critique of Schillerian aesthetic ideology as a ceaseless disarticulation of the body's frame: from the stories of Wilhelm's puppets and of Mignon's epileptic body and, finally, her fictional corpse in the Lehrjahre, to the dismemberment staged by vocational Bildung in the Wanderjahre, the body as figure-as non-natural, non-organic, disarticulable aggregate-has provided an allegory of the radical incoherence of textual production. The terms of this allegory are certainly not without relation to Goethe's rich and lifelong interest in natural philosophy: these stories of dismemberment emerge precisely because the body-and particularly the body's frame, the skeleton-presents itself so forcefully in this oeuvre as "a text on which all life and all that is human can be said to depend." Over and over Goethe's literary texts have asked what it means for "life" and "humanity" to depend on a text, a bone-text that must be read (lesen) as a gathering (zusammenlesen) that depends not on nature but on the possibility, always uncertain, that rhetorical figures are animated by a logos: "When I find a scattered skeleton, I can gather it [zusammenlesen] and put it together; for here eternal reason speaks through an analogue [Analogon], even if the skeleton be a giant sloth" (307/311). ${ }^{9}$ The allegories of reading that masquerade as Wilhelm Meister's Bildungsromane have told the story of reading as a gathering that scatters, a framing that disarticulates the meaning it ceaselessly disinters.

The poem is both a symptom and another text, another piece of this textual boneyard; as it distends the frame of the Wanderjahre it rehearses Mignon's story of dispersal and gathering once again. If one listens to Goethe's only known remarks about terza rima, communicated in a letter sent thirty years earlier to the then-living Schiller, the poem registers the pressure of deformation even in its form: terza rima, Goethe had written, "has no restfulness, and because of the continuous measures [fortschrittenden Räume] one can't close anywhere" (WA, 4:13, 71-72). ${ }^{10}$ The poem, to

8. See Viëtor, "Goethes Gedicht," 173, and Blackall, Goethe and the Novel, 261.

9. Viëtor mentions in this connection Goethe's late poem "Typus," in which the skeleton figures the type, the ideal norm informing material form: "Es ist nichts in der Haut, / Was nicht im Knochen ist" (AA, 1:539; cited in Viëtor, "Goethes Gedicht," 163). The skeleton thus appears here as the equivalent of Schiller's "pure ideal man" in the Aesthetic Education: as a kernel of destiny or Bildung. The empty husks and scattered bones that we have encountered in Goethe's texts, however, would suggest that the trope of the skeleton be read with some caution even in idealizing contexts.

10. The terza rima form appears rarely in the German poetic tradition, and, as noted above, 
be sure, finishes in conventional fashion with an extra line sealing off the stanza, and for that matter reinforces its closure with an aphorism structured as a chiasmus, as the text's language mirrors the exchange of properties that "Gott-Natur" dictates ("Wie sie das Feste läßt zu Geist verrinnen / Wie sie das Geisterzeugte fest bewahre").11 But the conclusiveness of this conclusion is undermined by the uncertain rhetorical status of the question that frames it. The question, "Was kann der Mensch im Leben mehr gewinnen, / Als daß sich Gott-Natur ihm offenbare?" may be taken as literal or "rhetorical": it obtains a note of urgency as soon as one suspects the untrustworthiness of the poem's "II" a suspicion that then triggers an endless interpretative spiral, since the sincere urgency or literalness of the speaker's question is being generated by the difficulty of deciding whether or not to take this speaker seriously. For the speaker is an enthusiast, a Schwärmer, whose hunger for spiritual election forces a suspiciously abrupt revelation at the end of the fifth stanza: a revelation offered as a fact rather than a question, but as such a self-flattering fact that it becomes a questionable one: "Doch mir Adepten war die Schrift geschrieben, / Die heiligen Sinn nicht jedem offenbarte." As signaled by the reiterated verb, "offenbaren," Gott-Natur has implicitly revealed herself in the divine script that underwrites the identification of the skull, but in doing so has turned both herself and the "I" into a question.

Thus alerted, one might begin to find other things odd about the poem's miniature Bildungsroman: the fact, for instance, that the narrative begins not with a katabasis or descent but in the grave; or that, despite the overeager tone of the revelation in stanzas five and following, the "I" fades into gerunds and reflexives as it wends its way toward the solar universe of meaning ("zu freiem Sinnen, / Zum Sonnenlicht andächtig hin mich wendend"). There is a curiously ghostly quality to this narcissistic narrator; and if he begins his narrative among the dead rather than "nel mezzo del camin di nostra vita," this is because his "life" in fact depends on the revelation in stanzas five and six, at which point, at the sight of a shape [Gebild], the narrator "frei und wärmefühlend mich erquickte, / Als ob ein Lebensquell

Goethe's oeuvre in this respect affords no exception. Apart from the poem under consideration, there are translations from Dante, and, significantly, Faust's monologue in the opening scene of Faust II, in which Faust awakes from death-like sleep into a new life of striving, oriented toward and deflected from the blinding light of the sun: "Sie tritt hervor! — und leider schon geblendet, / Kehr' ich mich weg, vom Augenschmerz durchdrungen [ . . . ] Am farbigen Abglanz haben wir das Leben" (HA, 3:148-49). It is possible that "Im ernsten Beinhaus" and Faust's monologue were written around the same time as the translations from the Inferno, which Goethe attempted after an intensive reading of Dante in August and September of 1826. (Schiller's skull entered Goethe's possession at the end of that September.) See Trunz, HA, 3:584, and Viëtor, "Goethes Gedicht," 178-83.

11. See Franz H. Mautner, “'Ist fortzusetzen': Zu Goethes Gedicht auf Schillers Schädel,” PMLA 59 (1944): 1156-62. 


\section{Phantom Formations}

dem Tod entspränge." This life-giving revelation is identified, tautologically, as an act of reading: "mir . . w war die Schrift geschrieben." The enthusiastic narrator is thus as much a reading-effect as is the "heiligen Sinn," "Form," or "gottgedachte Spur" that he discovers and bears forth. If he is a suspiciously hyperbolic narrator, this is because rhetoric has animated him. The story of this possibility is that of the impossible encounter of a minimal subject, an " $\mathrm{I}$ " who is in a certain sense neither alive nor dead, with equally indeterminate objects. For what the " $\mathrm{I}$ " beholds in the poem's opening lines is not precisely bones per se, but a grammar of bones: ". . . ich beschaute, / Wie Schädel Schädeln angeordnet paßten." The "I" here transforms into a perception the unperceivable differences that make language possible, summarized here in the untranslatable "passen" of skull with skull:12 the difference to be "seen" is the minimal mark of the dative, the " $\mathrm{n}$ " that differentiates "Schädel" from "Schädeln," organizing a potential stutter into a grammatical structure.

Like the tangled pile of puppets at the beginning of the Lehrjahre, these skulls and bones figure the material support of language as a system of differences: they figure, in other words, the uncertainty that makes possible all systems of articulation. This uncertainty is what the system at once effaces and reiterates as it comes into being as a system, as the "I" apostrophizes the bones, granting meaning to fragments, joints, and body parts, transforming the nonphenomenality of difference, the metonymy of skullon-skull, into the "gray time" of metaphor, in which skulls can function as containers of lost meaning ("dürre Schale .... / Welch herrlich edlen Kern sie auch bewahrte"), a loss that can then be reversed into a plenitude. The "I," however, is a product of this rhetorical process of animation rather than its source; its apostrophes-and its climactic discovery and appropriation of the "heiligen Sinn" - repeat an impersonal predicament: "They leave you no peace in the grave: driven / You'll be, up to the light of day." The motion upward toward meaning is endless, ungrounded, indifferent to the subjects and meanings it generates, dependent only on the random order of bones. "Lying crosswise," the bones are the skeleton truth of the poem's closing, idealizing chiasmus; they are the condition for skeletons, but are not skeletons; they are the frame, the Gestell, that makes the organic body possible, but, "scattered out of life's joint," they reveal the dependence of life, or meaning, on joints and articulations that are themselves meaningless, without pathos or interiority, alien to love ("Und niemand kann die dürre Schale lieben"), to memory ("was sie trugen, / Fragt niemand

12. In modern German,"passen" used intransitively means "to fit," but Viëtor comments that in eighteenth-century usage the word carried a temporal as well as a spatial meaning: the narrator would thus be seeing "how skull awaits skull" ("Goethes Gedicht," 148 n. 7). 
mehr"), and to the dialectical struggle of life and death ("die sich tödlich schlugen").

Such a material condition or "frame" should not, however, be mistaken for a foundation. The bones in this sense will always fail to form a true skeleton; they rather represent the very condition of being zerstreut, scattered or distracted, turned elsewhere, "driven / . . up to the light of day." Thus, in the Wanderjahre - if we are still "in" it; if there is such a thing as a "text" we can delimit, name, and inhabit, which is precisely what is at stake, and which is no longer at all certain - there can be no rest for the dead. Like the title character in Hitchcock's macabre comedy "The Trouble with Harry," the dead must constantly be dug up so as to be reburied more legitimately. The bodies, whether Mignon's, Schiller's, or the anonymous cadavers of Wilhelm's story of surgical Bildung, cannot stay in their graves; and because the frame of the text of death, burial, and resurrection is an ongoing rupture, even the poem on Schiller's skull does not mark the end of Wilhelm Meisters Wanderjahre. Appended to the poem, in editions of the Wanderjahre that follow the format of the Ausgabe letzter Hand, is the phrase "Ist fortzusetzen" ("To be continued") in parentheses. Whether the phrase refers to the poem, to the novel, or to some other, less definite, textual articulation is impossible to ascertain. ${ }^{13}$ As yet another scattered bone, another spur to meaning, another "sehr ernster Scherz" that resists being read, the phrase calls for interpretation and withdraws from comprehension, leaving us unable to decide whether its performative is a blessing or a curse. Nonetheless, the novel to which Goethe, perhaps arbitrarily, attached maxims, poems, and finally this dangling, fragmented phrase, narrates among other things the political violence attendant upon the nostalgic repression and aestheticization of such undecidability.

13. Since the phrase "Ist fortzusetzen" is set in the same typeface as the poem, most critics have tended to relate it to the poem; but since the poem's presence at the end of the novel also has to be explained, the question remains open. Blackall "find(s) no ready answer" (Goethe and the Novel, 261); Viëtor expresses uncertainty but suggests that the phrase refers not to the poem or the novel but to the "interpretation of the great world-mystery that becomes visible in the [poem's] closing formula" ("Goethes Gedicht," 183). For discussion see Viëtor, and the responses by Franz H. Mautner and Ernst Feise, and Viëtor's response to the responses, PMLA 59 (1944): 1156-72. 